\title{
Віддалені результати гемітиреоїдектомії та їх прогнозування у хворих на однобічний вузловий зоб на фоні автоімунного тиреоїдиту
}

\begin{abstract}
Мета роботи: визначення об’єму хірургічного втручання при вузловому зобі на фоні автоімунного тиреоїдиту з урахуванням активності процесів апоптозу та проліферації, індексу проліферативної активності.

Матеріали і методи. На пункційному матеріалі ЩЗ, отриманому від 80 хворих із гістологічно верифікованим діагнозом вузловий зоб на фоні автоімунного тиреоїдиту до хірургічного лікування та через $1,5-3$ роки після нього, проведені імуногістохімічні дослідження з використанням моноклональних антитіл проти Ki-67, Fas, FasL, Bcl-2 та P53 антигенів. За віддаленими результатами виділили дві групи хворих. До першої групи, яка становить 53 пацієнти, включені випадки, в яких не було розладів функції тиреоїдного залишку і змін об’єму залишеної частки залози порівняно з показниками до операції. Другу групу склали 27 хворих із клінічними і лабораторними ознаками післяопераційного гіпотиреозу середнього і тяжкого ступенів тяжкості, збільшенням об’єму залишеної частки залози на фоні прогресуючої лімфоїдної інфільтрації. Пацієнти обох груп у післяопераційному період отримували патогенетично обгрунтовану медикаментозну терапію автоімунного тиреоїдиту. Результати досліджень та їх обговорення. Проведені дослідження дозволяють розмежувати вибір об’єму операції гемітиреоїдектомія чи тиреоїдектомія залежно від функціональної спроможності Щз та показників апоптозу і проліферації у неураженій вузлом частці залози. Вважаємо, що тиреоїдектомія показана при поєднанні таких показників досліджуваних тестів: об’єм неураженої вузлом частки ЩЗ більший за 10 см³ $^{3}$ рівень ТТГ більше за 3,55 мОД/л, вільного $\mathrm{T}_{4}$ менше за 12,91 пмоль/л, рівень АТПО більше за 80,25 ОД/мл та АТТГ більше за 89,34 ОД/мл з показниками лімфопроліферативної активності та апоптозу, зокрема рівнів IПА Ki-67 вищими за 10,55 \%, IIPK FasL - за 51 \%, IIPK Bcl-2 - за 90 \%, та IIPK p53 нижче 50 \% і IIPK Fas нижче 43 \%.
\end{abstract}

Ключові слова: вузловий зоб на фоні автоімунного тиреоїдиту; апоптоз; проліферація в тканині щитоподібної залози; вибір об’єму хірургічного лікування.

Постановка проблеми і аналіз останніх досліджень та публікацій. Проблема автоімунного тиреоїдиту (АIT) - одна з актуальних клінічних проблем, вирішення якої вимагає подальших комплексних досліджень. Це визначається тим, що AIT є найпоширенішим захворюванням щитоподібної залози (ЩЗ) і становить 46 \% всієї тиреоїдної патології [1, 2].

Його поширеність становить від 6 до 10 \% серед дорослого населення і від 0,1 до 1,2 \% серед дітей $[1,3]$. Захворюваність AIT не має тенденції до зниження і зросла за останні 6-10 років в $10 \mathrm{i}$ більше разів [1-4].

Вузлоутворення на тлі AIT, за даними гістологічного дослідження, виявляють у 1/3 хворих [37]. Проблема вибору об’єму операцій на щитоподібній залозі при наявності вузлоутворення на тлі AIT гостро стоїть перед хірургами. Спрощений підхід, який базується тільки на даних УЗД, неминуче призводить до виконання необгрунтованих операцій, частота яких досягає 21 \% [6-8]. Водночас діагностика істинного вузлоутворення на тлі АІТ становить певні труднощі, що пов'язано зі специфічними змінами в тканині щитоподібної залози при цьому захворюванні [9-11].

Незважаючи на використання комплексу сучасних методів діагностики, не завжди можливо правильно встановити морфологічну природу вузлових утворень ЩЗ на тлі АІT.

На жаль, хімічні реагенти, що застосовуються при підготовці препаратів до морфологічних досліджень стандартним методом, блокують більшість антигенних детермінант. Тому імуноцитохімічні та морфологічні дослідження пункційного матеріалу проводять на окремих препаратах, що призводить до додаткових пункційних біопсій та унеможливлює морфологічну ідентифікацію реагуючих з антитілами клітин. Натомість оптимальним для доопераційної цитологічної діагностики $є$ такий варіант' коли цитоморфологічне й імуноцитохімічне дослідження проводять послідовно на одному й тому ж мазку пункційного матеріалу [12, 13].

Одним з механізмів пухлинної трансформації та прогресії $€$ порушення регуляції клітинного циклу з пригніченням апоптозу та активацією проліферації [14-19].

До маркерів регуляції апоптозу на даний час прийнято відносити мембранні рецептори Fas i Fas-L, білки Bcl-2; причому деякі дослідники відводять ключову роль протоонкогену Bcl-2, в регуляції апоптозу $[14,15]$. Крім білків сімейства $\mathrm{Bcl}-2$, регулятором апоптозу є ген-супресор ядерний фосфопротеїн р53 $[14,17,18]$. Даний ген бу- 
ває двох типів: p53 “дикого” типу, як вважають, стимулює апоптоз, тоді як мутантний р53 має аналогічний ефект на апоптоз, як білок Bcl-2, який пригнічує запрограмовану клітинну загибель. Існує близько 500 мутацій даного гена [18]. Мутації цього білка у хворих із злоякісними, доброякісними та автоімунними захворюваннями ЩЗ досліджені недостатньо $[11,18]$.

Крім чинників апоптозу, проліферативна активність представляє дуже важливу інформацію для визначення сутності передпухлинного стану та ï̈ прогнозу в плані малігнізації. Одним з імуногістохімічних маркерів проліферації є антиген Кi-67. Було показано, що Ki-67 присутній на ядрах клітин усіх стадій життєвого циклу, за винятком G0 і G1 початковій стадії. Після виходу клітини з мітотичного циклу антиген не виявляється [14-17, 19, 20]. Експресія цих молекул може виявлятися стандартними імуноцитохімічні методами, які досить просто інтегрувати в процес тонкоголкової аспіраційної пункційної біопсії (ТАПБ). Використання таких додаткових діагностичних методик, як імуногістохімія, можуть допомогти в інтерпретації “невизначених” змін, проте загальноприйняті стандартні молекулярні маркери на даний час відсутні $[10,11,13,15]$.

Вирішити ці проблеми конче необхідно’ адже від точності доопераційної цитологічної діагностики залежить правильний вибір тактики лікування’ своєчасність хірургічного лікування і його об’єму' а в результаті й виживання хворого $[11,12]$.

Мета роботи: визначення об’єму хірургічного втручання при вузловому зобі на фоні автоімунного тиреоїдиту з урахуванням активності процесів апоптозу та проліферації, індексу проліферативної активності.

Матеріали і методи. На базі Чернівецького Обласного ендокринологічного диспансеру обстежили 80 жінок з вузловими формами зоба на фоні автоімунного тиреоїдиту (ВЗАIT). Вік пацієнтів коливався від 23 до 72 років. Діагноз був виставлений клінічно, лабораторно (антитіла до тиреопероксидази (АТПО) - 60-250 ОД/мл; антитіла до тиреоглобуліну (АТТГ) - 60-500 ОД/мл; тиреотропний гормон (ТТГ) - 4-10 мОД/л, вільний тироксин - 7,7-14,2 пмоль/л (вТ4) за допомогою ультразвукового дослідження (УЗД) та підтверджений гістологічно після хірургічного лікування.

У всіх хворих було виконано операційне втручання за загальноприйнятими показами: великі розміри зоба із стисненням і зміщенням органів шиї (компресійний синдром), обструкції дихальних шляхів або при підозрі на злоякісне новоутворення Щ3 (III, IV, V група за класифікацією The Bethesda system for reporting thyroid cytopathology) за даними ТАПБ. Об’єм операції - гемітиреоїдектомія.

У дослідження не включали пацієнток з гіпертиреозом, маніфестним гіпотиреозом, артеріальною гіпертензією та серцево-судинними захворюваннями, тяжкою соматичною патологією і після настання менопаузи.

Всім пацієнтам проводили УЗ-контрольовану ТАПБ вузла, позавузлової паренхіми та паренхіми контрлатеральної частки ЩЗ, при цьому виконували не менш ніж 3 пункції, виходячи 3 того, що відсоток неадекватних пунктатів зменшується залежно від їх кількості в такій пропорції: одна пункція - 16 \%’ 2 пункції - 5’3 \%’ 3 пункції 4 \%’ 4 пункції - 2’6 \% [10].

Під час приготування мазків використовували розроблений і запатентований в Інституті ендокринології ім. В. П. Комісаренка спосіб відновлення активності антигенних детермінант, який дозволяє поєднати цитоморфологічні та імуноцитохімічні дослідження на одному цитологічному препараті і забезпечує можливість зіставлення морфологічних та імуноцитохімічних характеристик окремих клітинних елементів [9].

Цей метод дає достовірні результати на препаратах, що зберігались після фарбування не більше трьох діб. Після цього терміну результати нестабільні, що зумовлено процесами окислення деяких хімічних сполук на повітрі $[9,12,13]$. Для постановки імуногістохімічної реакції використовували моноклональні антитіла проти наступних антигенів: Mouse Human Ki-67 FITC Clone MIB-1; Anti-p53 Protein Monoclonal Antibody, FITC Conjugated, Clone DO-7; Mouse Anti-Human Apoptosis Regulator Bcl-2 (BCL2) Monoclonal, Unconjugated, Clone 124 antibody; Mouse Anti-Human CD95 Monoclonal Antibody, Unconjugated, Clone FAS 18; Mouse Anti-Human CD95L Monoclonal Antibody, Unconjugated, Clone NOK-1 фірми Dako Denmark A/S (Данія).

Результати імуногістохімічної реакції оцінювали методом напівкількісного аналізу, запропонованим О. К. Хмельницьким, за інтенсивністю забарвлення “+ -” - незначна, “+” - слабка, “++” помірна, “+++” - виражена [13]. Оцінку імунореактивних клітин вираховували за формулою IIPK $($ Fas, FasL, Bcl-2, P53) = N1 / N2 × 100 \%, де N1 число клітин імунопозитивних до Fas, FasL, Bcl-2, P53 рецепторів, N2 - загальне число ядр клітин на одному квадратному міліметрі. Оцінку ІПА вираховували за формулою ІПА $=$ NKi-67 / N заг. $\times$ 100 \%, де NKi-67 - загальна кількість ядер, імуно- 
позитивних до білка Ki-67, N заг. - загальна кіль-

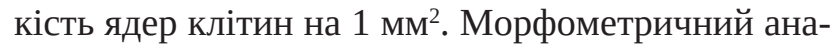
ліз проводили на мікроскопі Bresser BioScience Bino (Німеччина) з цифровою камерою Никон DSФіль, персональному комп'ютері з встановленим програмним забезпеченням NIS-Elements F 3.2.

Результати досліджень та їх обговорення. При імуногістохімічному дослідженні було виявлено, що у всіх випадках експресія Кi-67 на тиреоцитах мало слабкий “+” і помірний “++” характер, що проявлялося у вигляді коричневого або світло-коричневого фарбування ядер тиреоцитів у пацієнтів дослідної та контрольної групи. Кількість імунореактивних клітин у препараті розподілялася нерівномірно. У тиреоцитах біля осередків деструкції тиреоїдного епітелію та поблизу вогнищ лімфоїдної інфільтрації спостерігали підвищену експресію Кі-67, ІПА змінювався від 8,75 до 11,37 $\%$ (медіана 10,56 \%).

Було виявлено значну кількість тиреоцитів, що експресують Fas. Цитоплазматична мембрана тиреоцитів характеризувалася коричневим “++” і темно-коричневим “+++” забарвленням. Кількість імунореактивних клітин коливалась від 47 до 63 \% (медіана 55 \%). Примітно, що значна експресія “+++” спостерігалася в місцях з вираженою лімфоїдної інфільтрацією. Експресія FasL була вищою “+++” у фолікулах та прилеглих до них ділянках лімфоїдної інфільтрації “++”, що у співвідношенні клітин склала в середньому 46,10 \%.

Bcl-2 незначно “-” експресувалися тиреоїдним епітелієм на відміну від вогнищ лімфоїдної інфільтрації, цитоплазма якої фарбувалася в коричневий колір “+++”. При утворенні вогнищ лімфоїдної інфільтрації без чітких меж у щитоподібній залозі спостерігали рівномірне забарвлення цієї тканини в центрі і по периферії фолікулів. При сформованих зрілих фолікулах спостерігали відсутність забарвлення в центрі та інтенсивне забарвлення мантійної зони лімфоїдного фолікула. Лімфоїдна інфільтрація тканини поза вузликами інтенсивно експресувалась Bcl-2 в ділянці тиреоїдних фолікулів і в стромі залози. При аналізі кількості клітин, експресуючих Bcl-2, виявлено від 87 до 93 \% імунореактивних клітин (медіана $90 \%)$.

У нашому дослідженні висока експресія протеїну р53 спостерігалася в ядрах тиреоцитів та фолікулярних просвітах, при цьому виявлено яскраву позитивну реакцію з забарвленням ядер в темно-коричневий колір. Забарвлення на цей маркер мало локальний характер, при чому в одному полі зору визначались не більше 7-9 ядр. Концентрація імунореактивних клітин складала від 64 до 71 \% (медіана 65,5 \%).

За даними літератури, Ki-67 є одним з найбільш часто використовуваних імуногістохімічних маркерів у диференціальній діагностиці між доброякісними та злоякісними пухлинами в патології людини $[13,15]$. В результаті нашого дослідження було виявлено, що індекс проліферативної активності був найбільший в тканині ЩЗ з вогнищами лімфоїдної інфільтрації і найнижчий на тиреоцитах у пацієнтів обох груп. Проведене дослідження свідчить, що у пацієнтів на ВЗАІT в тканині ЩЗ відбувається пригнічення процесів апоптозу, про що свідчить зниження експресії Fas та FasL на тиреоцитах порівняно із ділянками лімфоїдної інфільтрації. Ко-експресія Fas i FasL в ділянках лімфоїдної інфільтрації навколо тиреоцитів свідчить про те, що безпосередньо Fas та FasL не беруть участь в апоптозі тиреоцитів, а індукують цей процес шляхом вироблення проапоптичних цитокінів. Цей висновок підтверджує незначна експресія Bcl-2 тиреоїдним епітелієм на відміну від тканини 3 лімфоїдною інфільтрацією, цитоплазма якої фарбувалася в коричневий колір “+++”. За даними літератури, модифікація білкової експресії р53 у тканині ЩЗ частіше корелює зі ступенем диференціації карциноми залози. У погано диференційованих карциномах експресія білка p53 може бути встановлена між 40 і 62 \%, тоді як у добре диференційованих карциномах вона не перевищує 25 \% $[14,20]$. Підвищену щільність р53-позитивних клітин можна пояснити мутаціями гена р53, що дозволяє клітинам знайти толерантність до апоптичної дії ефекторів імунної системи $[14,15,18,20]$.

За віддаленими результатами хірургічного лікування однобічного вузлового зоба на фоні автоімунного тиреоїдиту (термін спостереження від 1,5 до 3 років) виділили дві групи обстежених хворих. Пацієнти I групи - це 53 хворих, у яких не було порушення функціонального стану ЩЗ, а за даними УЗД розміри залишеної частки ЩЗ не відрізнялися від доопераційних.

Другу групу склали 27 хворих, у яких після гемітиреоїдектомії при повторному обстеженні за даними УЗД встановлено збільшення об’єму залишеної частки ЩЗ та формування вузла чи вузлів у ній на фоні вираженої лімфоїдної інфільтрації, а показники рівнів вТ4 і ТТГ вказували на наявність гіпотиреозу середнього ступеня тяжкості (табл. 1).

При ретроспективному порівнянні даних УЗД, гормональної спроможності ЩЗ, титру АТПО та АТТГ було встановлено, що у хворих I та II груп до операції об’єм неураженої вузлом частки зало- 
Таблиця 1. Порівняльна оцінка об'єму частки та функціонального стану щитоподібної залози у пацієнтів до та після гемітиреоїдектомії з приводу однобічного вузлового зоба на фроні автоімунного тиреоїдиту

\begin{tabular}{|c|c|c|c|c|}
\hline \multirow{2}{*}{ Показники } & \multicolumn{2}{|c|}{ I група (n=53) } & \multicolumn{2}{|c|}{ II група (n=27) } \\
\hline & до операції & після операції & до операції & після операції \\
\hline $\begin{array}{l}\text { Об’єм неураженої вузлом } \\
\text { частки ЩЗ }\left(\mathrm{cm}^{3}\right)\end{array}$ & $10,18 \pm 0,25$ & $9,27 \pm 0,23$ & $10,42 \pm 0,91$ & $20,86 \pm 1,17 *$ \\
\hline вТ4 (пмоль/л) & $15,52 \pm 0,19$ & $13,8 \pm 0,19$ & $13,02 \pm 0,21 *$ & $5,83 \pm 0,46^{*}$ \\
\hline ТТГ (мОД/л) & $2,12 \pm 0,14$ & $2,37 \pm 0,15$ & $3,08 \pm 0,45^{*}$ & $13,76 \pm 0,89 *$ \\
\hline АТПО (ОД/мл) & $73,21 \pm 0,19$ & $74,45 \pm 0,56$ & $82,44 \pm 1,15^{*}$ & $215,68 \pm 1,88 *$ \\
\hline АТТГ (ОД/мл) & $73,15 \pm 0,49$ & $78,49 \pm 0,49$ & $93,23 \pm 1,23 *$ & $135,27 \pm 1,52 *$ \\
\hline
\end{tabular}

Примітка. * - $<<0,05$ коефіцієнт вірогідності між групами.

зи достовірно не різнився, а різниця у показниках тиреоїдного статусу та антитіл до ТПО та ТГ була достовірною (табл. 1).

При імуногістохімічних дослідженнях пунктатів залишеної частки у цій групі пацієнтів було відмічено достовірне пригнічення апоптотичних процесів на фоні вираженої активації проліферативних процесів (табл. 2). Слід зазначити, що пацієнти обох груп у післяопераційному періоді отримували адекватну, патогенетично обгрунтовану консервативну терапію.

При порівнянні показників проліферації та апоптозу встановлено, що у пацієнтів II групи порівняно з показниками I групи вірогідно підвищеними були показники IПА Ki-67, IIPK FasL, IIPK Bcl-2 і зниженим - IIPK Fas та IIPK p53 (табл. 2).

Таблиця 2. Порівняльна оцінка маркерів проліферації та апоптозу у пацієнтів до та після гемітиреоїдектомії з приводу однобічного вузлового зоба на фоні автоімунного тиреоїдиту

\begin{tabular}{||l|c|c|c|c||}
\hline \multirow{2}{*}{\multicolumn{1}{|c|}{ Показники }} & \multicolumn{2}{c|}{ І група (n=53) } & \multicolumn{2}{c||}{ ІІ група $(\mathrm{n}=27)$} \\
\cline { 2 - 5 } & до операції & після операції & до операції & після операції \\
\hline IПА Ki-67 (\%) & $8,45 \pm 0,22$ & $8,85 \pm 0,23$ & $10,91 \pm 0,24^{*}$ & $11,22 \pm 0,19 *$ \\
\hline IIPK Fas (\%) & $51,21 \pm 0,17$ & $55,63 \pm 0,27$ & $41,16 \pm 0,54^{*}$ & $39,93 \pm 1,63 *$ \\
\hline IIPK FasL (\%) & $41,71 \pm 0,19$ & $45,63 \pm 0,19$ & $56,17 \pm 0,76^{*}$ & $64,26 \pm 0,98 *$ \\
\hline IIPK Bcl-2 (\%) & $86,71 \pm 0,18$ & $90,64 \pm 0,17$ & $98,33 \pm 0,85^{*}$ & $97,41 \pm 1,86^{*}$ \\
\hline IIPK p53 (\%) & $66,13 \pm 0,15$ & $65,19 \pm 0,15$ & $54,72 \pm 0,61^{*}$ & $48,14 \pm 1,19 *$ \\
\hline \hline
\end{tabular}

Примітка. * - $<<0,05$ коефіцієнт вірогідності між групами.

Очевидно, що достовірне зростання показників проліферації та пригнічення апоптозу, виявлені у віддаленому періоді після хірургічного лікування ВЗАІТ у хворих другої підгрупи, призводять до функціональної недостатності та гіперплазії залишеної частки щитоподібної залози. У зв'язку з цим виникає необхідність перегляду вибору об’єму операції у хворих на ВЗАІТ залежно від вираженності автоімунного процесу і функціональної спроможності залози.

Таким чином, проведений ретроспективний аналіз дозволяє нам розмежувати вибір об’єму операції - гемітиреоїдектомія чи тиреоїдектомія залежно від функціональної спроможності ЩЗ та показників апоптозу і проліферації у неураженій вузлом частці залози. При поєднанні досліджуваних показників: об'єм неураженої вузлом частки ЩЗ більший за 10 см$^{3}$, рівень ТТГ більше за
3,55 мОД/л, вільного Т 4 менше за 12,91 пмоль/л, рівень АТПО більше за 80,25 ОД/мл та АТТГ більше за 89,34 ОД/мл з показниками лімфопроліферативної активності та апоптозу, зокрема рівнів ІПА Ki-67 вищими за 10,55 \%, IIPK FasL - за 51 \%, IIPK Bcl-2 - за 90 \%, та IIPK p53 нижче 50 \% i IIPK Fas нижче 43 \% перевагу слід надавати тиреоїдектомії.

Висновки. 1. При однобічному вузловому зобі на фоні автоімунного тиреоїдиту з підвищеною проліферацією в тканині вузла та низькою в контрлатеральній частці, операцією вибору є гемітиреоїдектомія у поєднанні з розробленим комплексом консервативної терапії в післяопераційному періоді.

2. У пацієнтів з однобічним вузловим зобом на фоні автоімунного тиреоїдиту із вираженою проліферативною активністю в тканині контрла- 
теральної частки патогенетично обгрунтованою операцією є тиреоїдектомія.

3. Ризиком розвитку функціональної недостатності та гіперплазії контрлатеральної частки щитоподібної залози після гемітиреоїдектомії у пацієнтів на вузловий зоб на фоні автоімунного тиреоїдиту можна вважати об’єм неураженої вузлом

\section{СПИСОК ЛІТЕРАТУРИ}

1. Калоева А. А. Характер морфологических изменений при эндемическом зобе / А. А. Калоева, В. С. Боташева, Л. Д. Эркенова // Фундаментальные исследования. - 2015. № 1 (Ч. 1). - С. 30-40.

2. Tsyganenko O.S. Immunomorfological reaction in the thyroid tissue in patients with autoimmune thyroiditis in combination with nodular goiter / O. S. Tsyganenko, R. S. Voroschuk // Arta Medica. Nicholas Anestiadi, Tenth Congress of the Association of Surgeons of Moldova: Chisinau. - 2007. - Vol. 4 (25). - P. 5152.

3. Орлинская Н. Ю. Возможности гистологического и цитологического методов в диагностике различных состояний щитовидной железы / Н. Ю. Орлинская, П. С. Зубеев, Б. В. Саранцев // Сборник материалов Всероссийской конференции с международным участием "Клиническая морфология щитовидной железы”. - Белгород, 2004. - С. 42-43.

4. Возможности традиционной и жидкостной цитологии в сочетании с иммуноцитохимической детекцией некоторых молекулярных маркеров в дооперационной диагностике высокодифференцированного рака щитовидной железы / И. С. Берёзкина, Т. В. Саприна, А. П. Зима [и др.] // Клиническая и экспериментальная тиреоидология. - 2016. - № 1. C. $38-45$.

5. Рак щитоподібної залози у поєднанні з іншою тиреоїдною патологією: особливості клініки, діагностики та лікування : автореф. дис... на здобуття наукового ступеня д-ра мед. наук / М. В. Гульчій // Держ. установа "Ін-т ендокринології та обміну речовин ім. В. П. Комісаренка АМН України”. - К., 2008. - 36 c.

6. Kim H. S. Features of papillary thyroid microcarcinoma in the presence and absence of lymphocytic thyroiditis / H. S. Kim, Y. J. Choi, K. S. Yun // Endocrine Pathology. - 2010. - Vol. 21 (3). - P. 149-153.

7. Di Pasquale H. M. Pathologic features of Hashimoto's associated papillary thyroid carcinoma. / H. M. Di Pasquale, J. P. Palazzo, J. L. Rothstein // Hum. Pathol. - 2001. - Vol. 32 (1). - P. 24-30.

8. Бондаренко О. О. Использование онкомаркеров в морфологической диагностике эпителиальных опухолей щитовидной железы / О. О. Бондаренко, И. С. Шпонька, П. А. Гриценко // Морфологія. - 2010. - Т. 3, № 2 - С. 12-16.

9. Пат. № 23098 A UA MПK6 G01N33/50. Спосіб приготування морфологічних препаратів для імуноцитохімічного дослідження / Божок Ю. М.’ Тавокіна Л. В.’ Абраменко І. В.’

\section{REFERENCES}

1. Kaloyeva, A.A. Botasheva, V.S. \& Erkenova, L.D. (2015). Kharakter morfologicheskikh izmeneniy pri endemicheskom zobe [Character of morphological changes during endemic goiter]. Fundamentalinye issledovaniya - Basic Research, 1, 3040 [in Russian]. частки ЩЗ більшу за 10 см$^{3}$, рівень ТТГ більше за 3,55 мОД/л, вільного $\mathrm{T}_{4}$ менше за 12,91 пмоль/л, рівень АТПО більше за 80,25 ОД/мл та АТТГ більше за 89,34 ОД/мл, ІПА Кі-67 вище 10,55 \%, підвищення IIPK FasL вище 51 \%, підвищення IIPK Bcl-2 вище 90 \%, зменшення IIPK Fas нижче 43 \% та IIPK p53 нижче 50 \%.

Бєлоус Н. І.; опубл. 30. 06. 98’ Бюл. № 3.

10. Sheremet M. I. Analysis of a process of peroxidation, caspase-3 and caspase-8 in patients with autoimmune thyroiditis / M. I. Sheremet, V. O. Shidlovskyy, L. P. Sydorchuk // Journal of Education, Health and Sport. - 2015. - Vol. 5 (11). - P. 117-125. 11. Sheremet M. I. Assessment of proliferation and apoptosis markers in patients with autoimmune thyroiditis / M. I. Sheremet, V. O. Shidlovskyy, L. P. Sydorchuk // Journal of Education, Health and Sport. - 2016. - Vol. 6 (1). - P. 179-188.

12. Место тонкоигольной аспирационной биопсии в определении показаний к операции при узловом коллоидном зобе / П. С. Зубеев, Н. Ю. Орлинская, М. В. Матянин, Н. И. Тарасова // Ремедиум. - 2005. - Спецвыпуск Эндокринология. - С. 93-94.

13. Хмельницкий О. К. Цитологическая и гистологическая диагностика заболеваний щитовидной железы: руководство / О. К. Хмельницкий. - СПб. : СОТИС, 2002. - 286 с.

14. Kazakov S. P. The investigation of CD 95, p53, Bcl-2 and Ki-67 markers in autoimmune thyroid pathology patients / S. P. Kazakov, N. Ye. Kushlinsky // First Joint Meeting of European National Societies of Immunology Under the auspices of EFIS and 16th European Congress of Immunology: ECI. 2006. Sept. 6-9. Paris, France. -547 p.

15. Ganchevska P. Expression of proliferative antigens in human thyroid diseases / P. Ganchevska, K. Murdjev, V. Sarafian // Trakia Journal of Sciences. - 2004. - Vol. 2 (1). - P. 16-20.

16. Chen expression of Ki67 in papillary thyroid microcarcinoma and its clinical significance / Yu. Zhou, H-G. Jiang, N. Lu [et al.] // Asian Pacific Journal of Cancer Prevention. - 2015. Vol. 16 (4). - P. 1605-1608.

17. Choudhury M. Diagnostic utility of Ki67 and p53 immunostaining on solitary thyroid nodule - a cytohistological and radionuclide scintigraphic study / M. Choudhury, S. Singh, S. Agarwal // Indian J. Pathol. Microbiol. - 2011. - Vol. 54 (3). - P. 472-475.

18. Chumakov P. M. The function of the p53 gene: the choice between life and death. Biochemistry. - 2000. - No. 65. - P. 34-47. 19. Role of Ki-67 as a proliferative marker in lesions of thyroid / M. Pujani, B. Arora, M. Pujani [et al.] // Indian J. Cancer. - 2010. - Vol. 47 (3). - P. 304-307.

20. Хазієв I. В. Експресія онкомаркерів Кі-67 і p53 у фолікулярних неоплазіях щитоподібної залози / I. В. Хазієв, В. В. Сорокіна // Експериментальна і клінічна медицина. 2013. - T. 59, № 2. - С. 77-81.

2. Tsyganenko, O.S. \& Voroschuk, R.S. (2007). Immunomorfological reaction in the thyroid tissue in patients with autoimmune thyroiditis in combination with nodular goiter. Arta Medica. Nicholas Anestiadi, Tenth Congress of the Association of Surgeons of Moldova. Chisinau, 4 (25), 51-52. 
3. Orlinskaya, N.Yu., Zubeyev, P.S. \& Sarantsev, B.V. (2004). Vozmozhnosti gistologicheskogo i tsitologicheskogo metodov $\mathrm{v}$ diagnostike razlichnykh sostoyaniy shchitovidnoy zhelezy [Features of histological and cytological methods using in the diagnosis of various cancer states of thyroid]. Sbornik materialov Vserossiyskoy konferentsii s mezhdunarodnym uchastiyem "Klinicheskaya morfologiya shchitovidnoy zhelezy" - Collection of materials of the All-Russian conference with international participation "Clinical morphology of thyroid cancer". Belgorod [in Russian].

4. Berozkina, I.S. Saprina, T.V. \& Zima, A.P. (2016). Vozmozhnosti traditsionnoy i zhidkostnoy tsitologii $\mathrm{v}$ sochetanii s immunotsitokhimicheskoy detektsiyey nekotorykh molekulyarnykh markerov $\mathrm{v}$ dooperatsionnoy diagnostike vysokodifferentsirovannogo raka shchitovidnoy zhelezy [The problem of molecular diagnostic test value in the differential diagnosis of a thyroid gland nodule]. Klinicheskaya i eksperimentalnaya tireoidologiya - Clinical and Experimental Thyroidology,12, 1, 38-45 [in Russian].

5. Hulichii, M.V. Rak shchytopodibnoi zalozy u poiednanni z inshoiu tyreoidnoiu patolohiieiu: osoblyvosti kliniky, diahnostyky ta likuvannia [Cancer of the thyroid gland in the affected area of the thyroid pathology: especially of clinic, the diagnostic and treatment]: Doctor's thesis. Kyiv: Derzh. ustanova "In-t endokrynolohii ta obminu rechovyn im. V.P. Komisarenka AMN Ukrainy. [in Ukrainian].

6. Kim, H.S., Choi, Y.J. \& Yun, K.S. (2010). Features of papillary thyroid microcarcinoma in the presence and absence of lymphocytic thyroiditis. Endocrine Pathology, 21 (3), 149-153.

7. Di Pasquale, H.M., Palazzo, J.P. \& Rothstein, J.L. (2001). Pathologic features of Hashimoto's associated papillary thyroid carcinoma. Hum. Pathol., 32 (1), 24-30.

8. Bondarenko, O.O., Shponika, I.S. \& Gritsenko, P.A. (2010). Ispolzovaniye onko-markerov $\mathrm{v}$ morfologicheskoy diagnostike epitelialnykh opukholey shchitovidnoy zhelezy [The use of tumor markers in the diagnosis of morphological epithelial tumors of thyroid gland]. Morfologiya - Morphology, 3, (2) 12-16 [in Ukrainian].

9. Bozhok, Yu.M.' Tavokina, L.V.' Abramenko, I.V. \& Bielous, N.I. (1998) Pat. № 23098 A UA MPK6 G01N33/50. Sposib pryhotuvannia morfolohichnykh preparativ dlia imunotsytokhimichnoho doslidzhennia. Opubl. 30. 06. 98' Biul. № 3. [Preparation of morphological preparations for immunohistochemical study]. UA. Patent UA 23098;1998. [in Ukrainian]. 10. Sheremet, M.I., Shidlovskyi, V.O. \& Sydorchuk, L.P. (2015). Analysis of a process of peroxidation, caspase- 3 and caspase- 8 in patients with autoimmune thyroiditis. Journal of Education, Health and Sport., 5 (11), 117-125.

11. Sheremet, M.I., Shidlovskyi, V.O. \& Sydorchuk, L.P. (2016). Assessment of proliferation and apoptosis markers in patients with autoimmune thyroiditis. Journal of Education, Health and Sport., 6 (1), 179-188.

12. Zubeev, P.S., Orlinskaya, N.Yu., Matyanyn, M.V. \& Tarasova, N.I. (2005). Mesto tonkoygolinoy aspyratsyonnoy biopsii $\mathrm{v}$ opredelenii pokazaniy $\mathrm{k}$ operatsyi pri uzlovom kolloydnom zobe [Place of fine-needle aspiration biopsy in determining the indications for surgery in nodular colloid goiter.] Remedium, Spetsvypusk Endokrinologiya - Remedium. Special Edition Endocrinology, 93-94 [in Russian].

13. Khmelinytskiy, O.K. (2002). Tsitologicheskaya i gistologicheskaya diagnostika zabolevaniy shchitovidnoy zhelezy: Rukovodstvo [Cytological and histological diagnosis of thyroid diseases: guide]. St. Petersburg: SOTYS [in Russian].

14. Kazakov, S.P., \& Kushlinsky N.Ye. (2006). The investigation of CD 95, p53, Bcl-2 and Ki-67 markers in autoimmune thyroid pathology patients. First Joint Meeting of European National Societies of Immunology Under the auspices of EFIS and 16th European Congress of Immunology: ECI. 2006 Sept. 6-9; Paris, France: 547.

15. Ganchevska, P., Murdjev, K. \& Sarafian, V. (2004). Expression of proliferative antigens in human thyroid diseases. Trakia Journal of Sciences, 2 (1), 16-20.

16. Zhou, Yu., Jiang, H-G. \& Lu, N. (2015). Chen expression of Ki67 in papillary thyroid microcarcinoma and its clinical significance. Asian Pacific Journal of Cancer Prevention, 16 (4), 1605-1608.

17. Choudhury, M, Singh, S. \& Agarwal, S. (2011). Diagnostic utility of Ki67 and p53 immunostaining on solitary thyroid nodule - a cytohistological and radionuclide scintigraphic study. Indian J. Pathol. Microbiol., 54 (3), 472-475.

18. Chumakov, P.M. (2000). The function of the p53 gene: the choice between life and death. Biochemistry, 65, 34-47.

19. Pujani, M, Arora, B. \& Pujani, M. (2010). Role of Ki-67 as a proliferative marker in lesions of thyroid. Indian J. Cancer, 47 (3), 304-307.

20. Khaziyev, I.V. \& Sorokina, V.V. (2013). Ekspresiya onkomarkeriv Ki-67 i p53 v folikulyarnykh neoplaziyakh shchytopodibnoyi zalozy [Expression of tumor markers Ki67 and p53 in follicular thyroid neoplasia]. Eksperymentalna $i$ klinichna medytsyna - Experimental and Clinical Medicine, 59, 2, 77-81 [in Ukrainian].

Bukovyna State Medical University, Chernivtsi ${ }^{1}$,

I. Horbachevsky Ternopil State Medical University²

\section{REMOTE RESULTS OF HEMITHYROIDECECTOMY AND THEIR PROGNOSIS IN PATIENTS WITH UNILATERAL GOITER ON THE BACKGROUND OF AUTOIMMUNE THYROIDITIS}

The aim of the work: determining the volume of surgical intervention for nodular goiter combined with autoimmune thyroiditis, taking into account the activity of apoptosis and proliferation processes and the proliferative activity index.

Materials and Methods. Immunohistochemical studies using monoclonal antibodies against Ki-67, Fas, and FasL, Bcl-2, and P53 antigens were performed on a puncture material of thyroid gland from 80 patients with histologically verified diagnosis of nodular goiter on 
the background of autoimmune thyroiditis prior to surgical treatment and 1.5 to 3 years after it. According to remote results, two groups of patients were identified. The first group of 53 patients included cases in which there was no disturbance in the function of the thyroid gland and changes in the volume of the remaining part of the gland compared with the rates before the operation. The second group consisted of 27 patients with clinical and laboratory signs of postoperative hypothyroidism of moderate to severe severity, an increase in the amount of residual gland in the background of progressive lymphoid infiltration. Patients of both groups in the postoperative period received pathogenetically substantiated drug therapy for autoimmune thyroiditis.

Results and Discussion. The conducted studies allow differentiating the choice of volume of surgery - hemithyroidectomy or thyroidectomy, depending on the functional capacity of the thyroid and apoptosis and proliferation in the unharmed node of the lobe of the gland. We believe that thyroidectomy is indicated by combining the following indices of the tested tests: the volume of the unharmed nodule of the thyroid gland is greater than $10 \mathrm{~cm}^{3}$, the TSH level is greater than $3.55 \mathrm{mUN} / \mathrm{l}$, the free T4 is less than $12.91 \mathrm{pmol} / \mathrm{l}$, the thyroid peroxidase antibody level is greater than $80.25 \mathrm{UN} / \mathrm{ml}$ and thyroglobulin antibody more than $89.34 \mathrm{UN} / \mathrm{ml}$ with incidence of lymphoproliferative activity and apoptosis, in particular PAI (proliferative activity index) Ki-67 higher than 10.55\%, IRI (immunoreactive index) FasL - 51 \%, IRI Bcl-2 - for $90 \%$, and IRI p53 below $50 \%$ and IRI Fas below $43 \%$.

Key words: nodular goiter combined with autoimmune thyroiditis; needle biopsy; apoptosis; proliferation; choice of surgery.

\section{М. И. ШЕРЕМЕТ ${ }^{1}$, В. А. ШИДЛОВСКИЙ², Л. П. СИДОРЧУКํํ, А. В. ШИДЛОВСКИЙ²}

Буковинский государственный медицинский университет, Черновцы ${ }^{1}$

гВУЗ “Тернопольский государственный медицинский университет имени И. Я. Горбачевского МЗ Украины”2

\section{ОТДАЛЕННЫЕ РЕЗУЛЬТАТЫ ГЕМИТИРЕОИДЭКТОМИИ И ИХ ПРОГНОЗИРОВАНИЕ У БО.ЛЬНЫХ С ОДНОСТОРОННИМ УЗЛОВЫМ ЗОБОМ НА ФОНЕ АУТОИММУННОГО ТИРЕОИДИТА}

Цель работы: определение объема хирургического вмешательства при узловом зобе на фоне аутоиммунного тиреоидита с учетом активности процессов апоптоза и пролиферации, индекса пролиферативной активности.

Материалы и методы. На пункционном материале щитовидной железы, полученном от 80 больных с гистологически верифицированным диагнозом узловой зоб на фоне аутоиммунного тиреоидита к хирургическому лечению и через 1,5-3 года после него, проведенные имуногистохимические исследования с использованием моноклональных антител против Кі-67, Fas, FasL, Bcl-2, и P53 антигенов. По отдаленным результатам выделили две группы больных. К первой группе, которая составляет 53 пациента, включены случаи, у которых не было нарушений функции тиреоидного остатка и изменений объема оставленной доли железы по сравнению с показателями до операции. Вторую группу составили 27 больных с клиническими и лабораторными признаками послеоперационного гипотиреоза средней и тяжелой степеней тяжести, увеличением объема оставленной доли железы на фоне прогрессирующей лимфоидной инфильтрации. Пациенты обеих групп в послеоперационном периоде получали патогенетически обоснованную медикаментозную терапию аутоиммунного тиреоидита.

Результаты исследований и их обсуждение. Проведенные исследования позволяют разграничить выбор объема операции гемитиреоидэктомия или тиреоидэктомия в зависимости от функциональной способности щитовидной железы и показателей апоптоза и пролиферации в непораженной узлом доле железы. Считаем, что тиреоидэктомия показана при сочетании таких показателей исследуемых тестов: объем непораженной узлом доли щитовидной железы больше 10 см$^{3}$, уровень ТТГ больше 3,55 мЕд/л, свободного Т4 меньше 12,91 пмоль/ л, уровень АТПО больше 80,25 MЕ/мл и АТТГ больше 89,34 МЕ / мл с показателями лимфопролиферативной активности и апоптоза, в частности уровней иммунопролиферативной активности Кі-67 выше 10,55 \%, ИИРК (индекс иммунореактивных клеток) FasL - по 51 \%, ИИРК Bcl-2 - 90 \%, и ИИРК р53 ниже 50 \% и ИИРК Fas ниже 43 \%.

Ключевые слова: узловой зоб на фоне аутоиммунного тиреоидита; пункционная биопсия; апоптоз; пролиферация; объем операции. 